\title{
Cardiac rhabdomyoma in a slaughtered pig
}

\author{
Paula Reis Pereira ${ }^{1^{*}}$ Raquel Aparecida Sales da Cruz $^{2}$ Luciane Maria Jühlich ${ }^{3}$ \\ Luciana Sonne ${ }^{1}$ David Emílio Santos Neves de Barcellos ${ }^{3}$ David Driemeier $^{1}$
}

${ }^{1}$ Setor de Patologia Veterinária, Faculdade de Veterinária, Universidade Federal do Rio Grande do Sul (UFRGS), 91540-000, Porto Alegre, RS, Brasil. E-mail: paula.rpereira@hotmail.com. "Corresponding author.

${ }^{2}$ Laboratório de Patologia Veterinária, Hospital Veterinário, Universidade de Cuiabá (UNIC), Cuiabá, MT, Brasil.

${ }^{3}$ Setor de Suínos, Faculdade de Veterinária, Universidade Federal do Rio Grande do Sul (UFRGS), Porto Alegre, RS, Brasil.

ABSTRACT: Rhabdomyoma is a rare neoplasm of striated muscle that occurs predominantly in the myocardium. In animals, cardiac rhabdomyoma are observed as incidental lesions in slaughter pigs and have been rarely described in other species, such as cattle, dogs, and deer. This report describes a case of cardiac rhabdomyoma in a male pig at slaughter age that died suddenly in the pre-slaughter period. At necropsy, multiple nodules were observed in the right and left ventricular walls and the interventricular septum. Histopathological examination showed neoplastic proliferation composed of polyhedral cells, with vacuolated cytoplasm that sometimes presented a "spider cell" appearance. Histochemical staining with Schiff's periodic acid revealed glycogen granules in the cytoplasm of neoplastic cells. The neoplastic cells were positive for desmin, neuron-specific enolase, atrial natriuretic peptide, and vimentin by immunohistochemistry, to varying degrees. The anatomopathological and immunohistochemical findings observed in this case confirmed the diagnosis of cardiac rhabdomyoma, possibly originating from the Purkinje fibers.

Key words: pig, cardiac tumor, glycogen, spider cell, immunohistochemistry.

Rabdomioma cardíaco em um suíno de abate

\begin{abstract}
RESUMO: Rabdomioma é um neoplasma raro de músculo estriado que ocorre predominantemente no miocárdio. Em animais rabdomiomas cardíacos são observados como lesões incidentais em suinos de abate, raramente descrito em outras espécies como bovinos, cães e cervos. Neste relato descreve-se um caso de rabdomioma cardíaco em um suíno, macho, em idade de abate que morreu subitamente no periodo pré-abate. Na necropsia visualizou-se múltiplos nódulos nas paredes ventriculares direita e esquerda, e septo interventricular. O exame histopatológico mostrou proliferação neoplásica composta por células poliédricas, com citoplasma vacuolizado que por vezes apresentavam aspecto de "célula de aranha". Na coloração histoquimica de ácido periódico de Schiff evidenciaram-se grânulos de glicogênio no citoplasma das células neoplásicas. As células neoplásicas foram imunorreativas na imuno-histoquímica para desmina, enolase neurônio especifica, peptídeo natriurético atrial e vimentina em diferentes graus. Os achados anatomopatológicos e imuno-histoquímicos observados neste caso confirmam o diagnóstico de rabdomioma cardíaco, possivelmente com origem das fibras de Purkinje.

Palavras-chave: suíno, tumor cardíaco, glicogênio, célula de aranha, imuno-histoquímica.
\end{abstract}

Rhabdomyomas are benign solitary or multiple tumors that originate from striated muscle (COOPER \& VALENTINE, 2017), occurring in the myocardium, as well as in the skeletal muscles of the larynx and head region in humans and animals (COOPER \& VALENTINE, 2017). In domestic animals, they have been reported most frequently in pigs, guinea pigs (KOBAYASHI et al., 2010) and rarely in cattle (COOPER \& VALENTINE, 2017), deer (KOLLY et al., 2004), dogs (KIZAWA et al., 2002; RADI \& METZ, 2009), and bearded seals (KRAFSUR et al., 2014).

Cardiac rhabdomyoma is characterized by large glycogen containing vacuolated cells and is also referred to as rhabdomyomatosis, congenital glycogen tumor, circumscribed glycogen storage disease, nodular glycogen degeneration, nodular glycogen, and nodular glycogen infiltration (KIZAWA et al., 2002). Cardiac rhabdomyoma must be differentiated from glycogen storage disease (WALVOORT, 1983) and other differential cardiac tumors as lymphoma, hemangiosarcoma and hemangioma (LOYNACHAN, 2012). This report describes the histopathological and immunohistochemical findings of a case of cardiac rhabdomyoma in a slaughter pig.

A male pig of commercial lineage and slaughter age (165-170 days) was shipped to the slaughterhouse and found dead in the transport truck 
during pre-slaughter handling. The pig was submitted to routine necropsy examination, and macroscopically the heart was moderately globose, there was stomach ulcer and cranioventral pulmonary consolidation, all other organs had no significant gross lesions. On the cut surface of the ventricular walls, a nodule of $2.0 \times 1.5 \mathrm{~cm}$ was observed in the right ventricle, extending from the myocardium to the ventricular chamber (Figure 1A). The nodule was circumscribed, well demarcated, apparently encapsulated, yellowishwhite, and firm. Multiple nodules, varying from 0.3 to $0.5 \mathrm{~cm}$ in diameter and similar in appearance to the right ventricular nodule, were also observed in the left ventricular myocardium and the interventricular septum. Representative samples of all organs were fixed in $10 \%$ formalin, and the tissues were processed routinely and embedded in paraffin. Three micrometer sections of the paraffin blocks were made and stained with hematoxylin and eosin (HE) and Schiff's periodic acid (PAS). Serial sections were subjected to immunohistochemistry (IHC), with the following antibodies, according to previously described protocols (PEREIRA et al., 2017): vimentin (clone V9; 1:200; Zymed), pan-cytokeratin (clone AE1/AE3; 1:80; DakoCytomation) and neuron specific enolase (NSE) (1:200; DakoCytomation). Antibodies of desmin and atrial natriuretic peptide (ANP) according to described protocols (CRUZ, 2017): desmin (1:300; DakoCytomation) and ANP (1:50; Abcam). The detection method and chromogen, used for all antibodies were the Labelled Streptavidin-Biotin System - Horseradish Peroxidase (DakoCytomation) and 3,3'-diaminobenzidine (DAB) (DakoCytomation), respectively.

Microscopically, a neoplastic proliferation well circumscribed but not encapsulated, composed by polyhedral cells was observed, arranged in cohesive bundles interspersed with scarce fibrovascular stroma. Cells had distinct borders with ample eosinophilic cytoplasm that often contained multiple vacuoles. Some cells had a centrally-located nucleus, with lacy cytoplasm, giving the appearance of a "spider cell". The nuclei were oval with finely dotted chromatin and unique nucleoli. There was moderate anisocytosis and anisokaryosis. Mitotic figures were not observed (Figure 1B). Areas of pulmonary consolidation corresponded microscopically to necrotizing bronchiolitis compatible with Influenza pneumonia.

On PAS staining, glycogen granules were detected in the cytoplasm of the neoplastic cells. Neoplastic cells were also positive for desmin (Figure 1C), NSE (Figure 1D), ANP (Figure 1E), and vimentin (Figure 1F) by IHC to varying degrees. Discrete immunoreactivity was observed for vimentin, moderate for ANP, and accentuated for desmin and NSE, whereas there was no immunolabeling for pan-cytokeratin.

The diagnosis of cardiac rhabdomyoma in this study was based on the pathological and immunohistochemical findings. Neoplasm was observed in a slaughter pig, generally is considered an incidental slaughter lesion(COOPER \& VALENTINE (2017), but in this case, the neoplasm associated with stomach ulcer and the Influenza lesions observed in the lung contributes to the pig death. Sudden death may occur due to the interference in the myocardial conduction that these tumors can potentially cause, as suggested by MCEWEN (1994). Mortality in transported pigs may still occur due to stress, mainly caused by ambient temperature and transport distance (VOSLAROVA et al., 2017).

The present report describes a multifocal distribution of neoplastic nodules, the largest of which was in the right ventricle; however, MCEWEN (1994) reported that rhabdomyoma is more common in the left ventricle, butalso it can be observed in the interventricular septum and the right ventricle (TANIMOTO \& OHTSUKI, 1995). On gross examination nodules, 0.3 to $2.0 \mathrm{~cm}$ in diameter, were observed and were well delimited, firm, and yellowish-white, similar to those previously described (OMAR, 1969; TANIMOTO \& OHTSUKI, 1995; KIZAWA et al., 2002; KOLLY et al., 2004; JACOBSEN et al., 2010; KRAFSUR et al., 2014). When the nodules project into the chamber, they are very susceptible to hemorrhage and necrosis and may become cystic (ROBINSON \& ROBINSON, 2016); however, cyst formation, hemorrhage and necrosis were not observed in this case.

Histologically, neoplastic cells had markedly distended cytoplasm that was eosinophilic and often vacuolated, as is described in cases of other species (OMAR, 1969; JACOBSEN et al., 2010; KRAFSUR et al., 2014). The described "spider cells" were also observed in other reports (OMAR, 1969; TANIMOTO \& OHTSUKI, 1995; KOLLY et al., 2004; JACOBSEN et al., 2010) and, this aspect occur after routine processing, which causes the loss of glycogen (TANIMOTO \& OHTSUKI, 1995; RADI \& METZ, 2009). ROBINSON \& ROBINSON (2016) also described areas of fibrosis, however they were not observed in this case.

Cardiac rhabdomyoma must be differentiated from glycogen storage disease, which is characterized by accumulation of glycogen in the heart, skeletal muscle, liver, kidneys, or muscle layer of the esophagus (WALVOORT, 1983), in this case we did not observe lesions in other organs. Other differential 


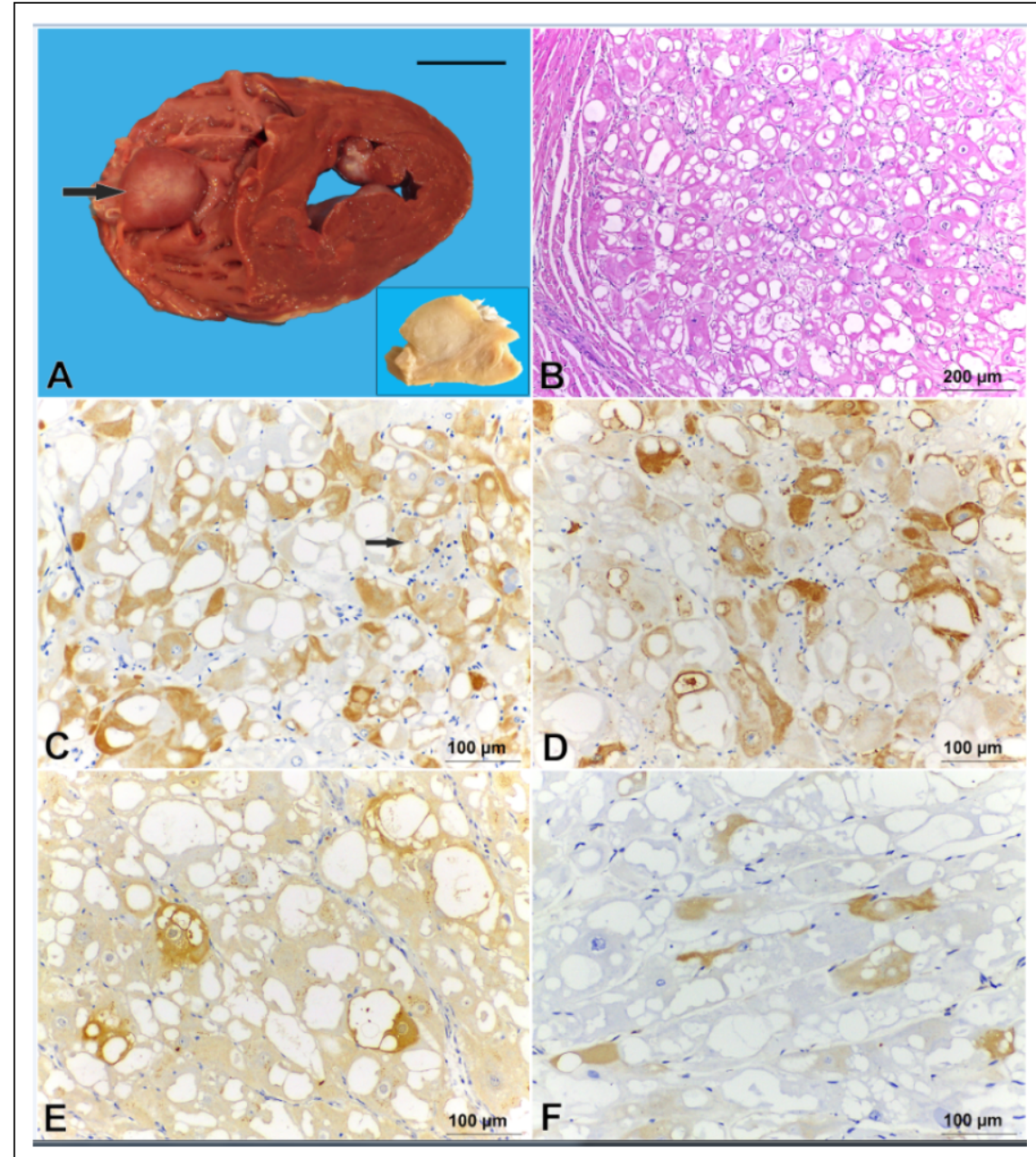

Figure 1 - Cardiac rhabdomyoma in a slaughter pig. (A) Nodule of $2.0 \times 1.5 \mathrm{~cm}$ observed in the wall of the right ventricle (arrow). Inset: nodule was circumscribed and yellowishwhite. Bar: $2.0 \mathrm{~cm}$. (B) Neoplasm composed of polyhedral cells with ample eosinophilic cytoplasm that is often vacuolated, with some cells presenting "spider cell" appearance. HE, Bar: $200 \mu \mathrm{m}$. (C) Neoplastic cells positive for desmin, with some cells presenting "spider cell" appearance (arrow). Chromogen DAB, Bar: 100 $\mu$ m. (D) Accentuated immunoreactivity for NSE in the neoplastic cells. Chromogen DAB, Bar: $100 \mu \mathrm{m}$. (E) Moderate immunoreactivity for ANP in the neoplastic cells. Chromogen DAB, Bar: $100 \mu \mathrm{m}$. (F) Discrete immunoreactivity for vimentin in the neoplastic cells. Chromogen DAB, Bar: $100 \mu \mathrm{m}$.

cardiac tumors are lymphoma, hemangiosarcoma and hemangioma (LOYNACHAN, 2012).

On PAS staining, glycogen granules were detected in the cytoplasm of the neoplastic cells, confirming glycogen content similar to that observed in several studies (OMAR, 1969; TANIMOTO \& OHTSUKI, 1995; KIZAWA et al., 2002; KOLLY et al., 2004; RADI \& METZ, 2009; JACOBSEN et al., 2010; KOBAYASHI et al., 2010). Immunoreactivity was observed in the cytoplasm of the neoplastic cells for desmin, NSE, ANP, and vimentin, as described by other authors (JACOBSEN et al., 2010; EL SHARABY et al., 2001). Discrete immunoreactivity for vimentin and accentuated for desmin and NSE was also describe by JACOBSEN et al. (2010). As reported by TANIMOTO \& OHTSUKI (1995), there was no immunolabeling for cytokeratin.

The histogenesis of rhabdomyoma is still uncertain, some authors suggest that they are hamartomas (ROBINSON \& ROBINSON, 2016), while others have 
investigated whether the cells are derived from the striated myocardium (COOPER \& VALENTINE, 2017) or Purkinje fibers (TANIMOTO \& OHTSUKI, 1995). To confirm the origin, studies have been performed, in which ANP immunolabeling has already been observed in the Purkinje fibers of different species (HANSSON et al., 1997). BIONDO et al. (2003) demonstrated ANP immunoreactivity was restricted to the atria, no marked in ventricular cardiomyocytes of healthy cats. TANIMOTO \& OHTSUKI (1995) demonstrated that immunoreactivity for vimentin may reflect the development of Purkinje fibers from multipotent cardiomyocyte precursors during embryogenesis. Based on the immunohistochemical findings in this case that are, very similar to those observed by JACOBSEN et al. (2010), with immunoreactivity in the neoplastic cells for desmin, NSE, ANP, and vimentin, suggested that the tumor in this case originated from the Purkinje fibers.

\section{ACKNOWLEDGEMENTS}

The authors are grateful to Conselho Nacional de Desenvolvimento Científico e Tecnológico (CNPq) and Coordenação de Aperfeiçoamento de Pessoal de Nível Superior (CAPES).

\section{BIOETHICS AND BIOSSECURITY COMMITTEE APPROVAL}

We authors of the article entitled "Cardiac rhabdomyoma in a slaughter pig" declared, for all due purposes, the project that gave rise to the present data of the same has not been submitted for evaluation to the Ethics Committee of the Universidade Federal do Rio Grande do Sul (UFRGS), but we are aware of the content of the Brazilian resolutions of the Conselho Nacional de Controle de Experimentação Animal (CONCEA) $<$ http://www.mct.gov.br/ index.php/content/view/310553.html $>$ if it involves animals. Thus, the authors assume full responsibility for the presented data and are available for possible questions, should they be required by the competent authorities.

\section{DECLARATION OF CONFLICTING INTERESTS}

The authors declare no conflict of interest. The founding sponsors had no role in the design of the study; in the collection, analyses, or interpretation of data; in the writing of the manuscript, and in the decision to publish the results.

\section{AUTHORS' CONTRIBUTIONS}

The authors contributed equally to the manuscript.

\section{REFERENCES}

COOPER, B.J.; VALENTINE, B.A. Tumors of muscle. In: MEUTEN, D.J. Tumors in Domestic Animals. Iowa: John Wiley \& Sons, 2017. Cap.11, p. 425-466.
CRUZ, R.A.S. Dilated cardiomyopathy in swine in Brazil. 2017. 63f. Thesis (Doctorate in Veterinary Medicine) - Postgraduate Course in Veterinary Medicine, Federal University of Rio Grande do Sul. Available from: <http:/hdl.handle.net/10183/163408>. Accessed: Aug. 10, 2018.

BIONDO, A.W. et al. Immunohistochemistry of atrial and brain Natriuretic Peptides in Control Cats and Cats with Hypertrophic Cardiomyopathy. Veterinary Pathology, v. 40, p. 501-506, 2003. Available from: <http://journals.sagepub.com/doi/pdf/10.1354/ vp.40-5-501>. Accessed: Aug. 10, 2018. doi: 10.1354/vp.40-5-501.

EL SHARABY, A.A. et al. Immunohistochemical demonstration of leu-7 (HNK-1), neurone-specific enolase (NSE) and protein-gene peptide (PGP) 9.5 in the developing camel (Camelus dromedarius) heart. Anatomy Histology Embryology, v. 30, p. 321-325, 2001. Available from: <https://onlinelibrary.wiley.com/doi/abs/10.10 46/j.1439-0264.2001.00343.x>. Accessed: Jan. 05, 2018. doi: 10.1046/j.1439-0264.2001.00343.x.

HANSSON, M. et al. Natriuretic peptide immunoreactivity in nerve structures and Purkinje fibres of human, pig and sheep hearts. Histochemical Journal, v. 29, n. 4, p. 329336, 1997. Available from: <https://link.springer.com/content/ pdf/10.1023\%2FA\%3A1026478616039.pdf>. Accessed: Jan. 07, 2018. doi: 10.1023/A:1026478616039.

JACOBSEN, B. et al. Proposing the term purkinjeoma: Protein Gene Product 9.5 Expression in 2 Porcine Cardiac Rhabdomyoma Indicates Possible Purkinje Fiber Cell Origin. Veterinary Pathology, v. 47, n. 4, p. 738-740, 2010. Available from: <http:// journals.sagepub.com/doi/pdf/10.1177/0300985810364525>. Accessed: Jan. 05, 2018. doi: 10.1177/0300985810364525.

KIZAWA, K. et al. Cardiac rhabdomyoma in a Beagle dog. Journal of Toxicologic Pathology, v. 15, n. 1, p.69-72, 2002. Available from: <https://www.jstage.jst.go.jp/article/tox/15/1/15_1_69/_ pdf $>$. Accessed: Jan. 05, 2018. doi:10.1293/tox.15.69.

KOBAYASHI, T. et al. ACardiac rhabdomyoma in a guinea pig. Journal of Toxicologic Pathology, v. 23, n. 2, p. 107-110, 2010. Available from: $<$ https://www.ncbi.nlm.nih.gov/pmc/articles/PMC3234645/pdf/tox-23107.pdf $>$. Accessed: Jul. 24, 2018. doi: 10.1293/tox.23.107.

KOLLY, C. et al. Cardiac rhabdomyoma in a juvenile fallow deer (Dama dama). Journal of Wildlife Diseases, v. 40, n. 3, p. 603606, 2004. Available from: <https://doi.org/10.7589/0090-355840.3.603>. Accessed: Jan. 06, 2018. doi: 10.7589/0090-355840.3.603.

KRAFSUR, G. et al. Histomorphologic and immunohistochemical characterization of a Cardiac Purkinjeoma in a Bearded Seal (Erignathus barbatus). Case Reports in Veterinary Medicine, v. 2014. Available from: <http://dx.doi.org/10.1155/2014/103279>. Accessed: Jan. 06, 2018. doi: 10.1155/2014/103279.

LOYNACHAN, A.T. Cardiovascular and hematopoietic systems. In: ZIMMERMAN, J.J.; KARRIKER, L.A.; RAMIREZ, A.; SCHWARTZ, K.J.; STEVENSON, G.W. (Eds). Disease of swine. Iowa: Iowa State Press, 2012. Cap. 14. p.197.

MCEWEN, B.J.E. Congenital cardiac rhabdomyomas in red wattle pigs. The Canadian Veterinary Journal, v. 35, p. 4849, 1994. Available from: <https://www.ncbi.nlm.nih.gov/pmc/ articles/PMC1686235/pdf/canvetj00350-0050.pdf >. Accessed: Jan. 07, 2018. 
OMAR, A. R. Congenital cardiac rhabdomyoma in a pig. Pathologia veterinária, v. 6, n. 5, p.469-474, 1969. Available from: <http://journals.sagepub.com/doi/pdf/10.1177/0300985869 00600511>. Accessed: Jan. 07, 2018.

PEREIRA, P. R. et al. Facial nerve ganglioneuroblastoma in a feline leukemia virus-positive cat. Ciência Rural, v.47, n.05, e20160675, 2017. Available from: $<$ http://www.scielo.br/scielo.php?script=sci arttext\&pid=S0103-84782017000500551>. Accessed: Aug. 10, 2018. doi: $10.1590 / 0103-8478 \mathrm{cr} 20160675$.

RADI, Z.A.; METZ, A. Canine cardiac rhabdomyoma. Toxicologic Pathology, v. 37, n. 3, p. 348-350, 2009. Available from: <http:// journals.sagepub.com/doi/pdf/10.1177/0192623309332991>. Accessed: Jan. 05, 2018. doi: 10.1177/0192623309332991.

ROBINSON, W.F.; ROBINSON, N.A. Cardiovascular system. In: MAXIE, M.G. Jubb, Kennedy, and Palmer's Pathology of Domestic Animals, 6.ed. Missouri: Elsevier, 2016. v. 3, Cap.1. p. 2-101.
TANIMOTO, T.; OHTSUKI, Y. The pathogenesis of socalled cardiac rhabdomyoma in swine: a histological, immunohistochemical and ultrastructural study. Virchows Archiv, v. 427, n. 2, p. 213-221, 1995. Available from: <https://link. springer.com/content/pdf/10.1007/BF00196528.pdf>. Accessed: Jan. 08, 2018

VOSLAROVA, E. et al. Transport losses in finisher pigs: impact of transport distance and season of the year. Asian-Australasian Journal of Animal Sciences, v.30, n.1, p.119-124, 2017. Available from: <https://doi.org/10.5713/ajas.16.0265>. Accessed: Aug. 10, 2018. doi: 10.5713/ajas.16.0265.

WALVOORT, H.C. Glycogen storage diseases in animals and their potential value as models of human disease. Journal of Inherited Metabolic Disease, v. 6, n. 1, p. 3-16, 1983. Available from: $\quad<$ https://link.springer.com/article/10.1007/BF02391186>. Accessed: Jan. 05, 2018. 